\title{
Nutritional Relationship between Bemisia tabaci and Its Primary Endosymbiont, Portiera aleyrodidarum, during Host Plant Acclimation
}

\author{
Fang-Yu Hu and Chi-Wei Tsai *D \\ Department of Entomology, National Taiwan University, Taipei 106, Taiwan; r06632002@ntu.edu.tw \\ * Correspondence: chiwei@ntu.edu.tw; Tel.: +886-2-3366-5576
}

Received: 16 June 2020; Accepted: 1 August 2020; Published: 4 August 2020

Simple Summary: Plant sap-sucking insects commonly have established mutualistic relationships with bacteria that live within their bodies and often provide nutrients that are lacking in the insect's diet. The sweet potato whitefly (Bemisia tabaci) harbors one primary and up to seven secondary endosymbiotic bacteria. The primary endosymbiont of $B$. tabaci is already known to play a critical role in providing necessary nutrients for $B$. tabaci. Our objective was to study the relationship among B. tabaci, its primary endosymbiont, and the host plant through the effects of host plant shifting and acclimation, that is, physiological adjustments as an insect becomes accustomed to a new host plant over several generations. The results showed that host shifting from Chinese kale to cotton plants led to a decrease in the fecundity of $B . t a b a c i$ in the first generation, which was restored after 10 generations of acclimation, and that its developmental time was also decreased by the tenth generation. Furthermore, essential amino acid biosynthesis genes of its primary endosymbiont were differentially regulated after $B$. tabaci had become acclimated to cotton plants. We speculate that the primary endosymbiont has a close nutritional relationship with $B$. tabaci during host plant acclimation.

\begin{abstract}
Plant sap-sucking insects commonly have established mutualistic relationships with endosymbiotic bacteria that can provide nutrients lacking in their diet. Bemisia tabaci harbors one primary endosymbiont, Portiera aleyrodidarum, and up to seven secondary endosymbionts, including Hamiltonella defensa and Rickettsia sp. Portiera aleyrodidarum is already known to play a critical role in providing necessary nutrients for B. tabaci. In the present study, the relationship among B. tabaci, its primary endosymbiont, and the host plant were examined through the effects of host plant shifting and acclimation. Bemisia tabaci was transferred from Chinese kale to four different host plants, and the effects on both its performance and the expression levels of nutrient-related genes of P. aleyrodidarum were analyzed. The results showed that host shifting from Chinese kale to cotton plants led to a decrease in the performance of $B$. tabaci in the first generation, which was restored after 10 generations of acclimation. Furthermore, the expression levels of essential amino acid biosynthesis genes of P. aleyrodidarum were found to be differentially regulated after B. tabaci had acclimated to the cotton plants. Host plant shifting and acclimation to cucumber, poinsettia, and tomato plants did not affect the fecundity of $B$. tabaci and the expression levels of most examined genes. We speculate that P. aleyrodidarum may help B. tabaci improve its performance and acclimate to new hosts and that P. aleyrodidarum has a close nutritional relationship with its host during host plant acclimation.
\end{abstract}

Keywords: cotton; developmental time; essential amino acids; fecundity; survival rate

\section{Introduction}

Hemipteran insects commonly harbor endosymbiotic bacteria [1], which can be categorized into two groups. Primary endosymbionts, which can synthesize necessary nutrients lacked by their hosts, 
are often located in specialized cells called bacteriocytes and have an obligate mutualistic relationship with their host [2]. Secondary endosymbionts may occur in bacteriocytes or in other tissues and usually have a facultative symbiotic relationship with their host. While primary endosymbionts are normally vertically transmitted from mother to offspring, secondary endosymbionts can be transmitted either vertically or horizontally [3].

Endosymbionts in insects have diverse functions, such as defense against natural enemies [4,5], defense against pathogens [6,7], body color [8], thermal tolerance [9,10], susceptibility to insecticides [11,12], vector competence to plant viruses [13-15], and reproduction [16]. They can be mutualistic, neutral, or parasitic to host insects [17]. Generally, these effects are associated with secondary endosymbionts.

Bemisia tabaci (Hemiptera: Aleyrodidae) is a species complex including at least 39 morphologically indistinguishable species [18-20], of which Middle East-Asia Minor 1 (MEAM1) putative species and Mediterranean (MED) putative species are widely distributed throughout the world. To date, $B$. tabaci species complex has been reported to harbor one primary endosymbiont, Portiera aleyrodidarum, and up to seven secondary endosymbionts, Hamiltonella defensa, Rickettsia sp., Wolbachia sp., Arsenophonus sp., Fritschea sp., Cardinium sp., and Hemipteriohilus sp. [21].

Bemisia tabaci is a polyphagous insect that can survive and reproduce on various host plants. To survive on a new host plant, $B$. tabaci needs physiological adjustment to be accustomed to the distinct physiological condition of the new host, which is termed acclimation. Malka et al. [22] suggests that $B$. tabaci MEAM1 has a detoxification mechanism, which helps it acclimate to new host plants. Besides the detoxification capability of B. tabaci itself, the primary endosymbiont, P. aleyrodidarum, of $B$. tabaci also plays a critical role in providing necessary nutrients for its hosts. An analysis of the $P$. aleyrodidarum genome has identified numerous biosynthesis genes of essential amino acids and carotenoids that are lacking in the genome and the diet of B. tabaci, indicating that P. aleyrodidarum has a nutritional mutualistic relationship with B. tabaci [23-27]. Buchnera sp. in Acyrthosiphon pisum has also been shown to possess crucial genes for amino acid biosynthesis and cooperates with its host to produce essential amino acids [28]. Santos-Garcia et al. [29] also reported that the gut-associated bacteria in B. tabaci MEAM1 may be beneficial during host plant shifting and acclimation.

When a polyphagous insect feeds and lives on a new host plant, it becomes accustomed to the distinct nutritional condition of the new host by adjusting its physiology. Due to the nutritional mutualistic relationship between P. aleyrodidarum and B. tabaci, we hypothesized that host plant acclimation is associated with this nutritional mutualistic endosymbiont. To advance the current knowledge of endosymbionts in plant sap-sucking insects, the present study determined the effects of host plant shifting and acclimation on the performance of B. tabaci MEAM1. Furthermore, the expression of nutrient-related genes of $P$. aleyrodidarum were examined after host plant shifting and acclimation. Unfortunately, the genes of $P$. aleyrodidarum are still unable to be manipulated artificially to date, including knockdown and/or overexpression, so we cannot directly demonstrate whether P. aleyrodidarum helps B. tabaci improve its performance and acclimate to new host plants. This is the first study examining changes in the expression of nutrition-related genes of insect endosymbiotic bacteria in relation to host plant acclimation.

\section{Materials and Methods}

\subsection{Insect and Plants}

A colony of $B$. tabaci MEAM1 species (mtCO1 sequence is identical to GenBank accession number EU427726) [30] was reared on Chinese kale (Brassica oleracea cv. Alboglabra Group) for five years (more than 85 generations) in insect-proof net cages $(30 \times 30 \times 30 \mathrm{~cm}$, Megaview, Taichung, Taiwan) at $28 \pm 2{ }^{\circ} \mathrm{C}$ and under a photoperiod of L:D 16:8 h. The laboratory colony was confirmed as harboring P. aleyrodidarum, H. defensa, and Rickettsia sp. by a PCR assay as described in Ansari et al. [31], and they were free of Wolbachia sp., Arsenophonus sp., Fritschea sp., Cardinium sp., and Hemipteriohilus sp. 
The host plants of $B$. tabaci used for the present study were Chinese kale, cotton (Gossypium barbadense), cucumber (Cucumis sativus cv. hualu), poinsettia (Euphorbia pulcherrima), and tomato (Solanum lycopersicum cv. ANT22), which are common host plants of B. tabaci MEAM1 from different families. Chinese kale, cotton, cucumber and tomato plants were grown from seeds, and poinsettia plants were propagated by cutting. All plants were grown at $28 \pm 2{ }^{\circ} \mathrm{C}$ and under a photoperiod of L:D 16:8 $\mathrm{h}$ in environmental chambers. For the experiments, Chinese kale, cotton and tomato plants with 4-6 leaves, cucumber plants with 3-4 leaves, and poinsettia with 10-15 leaves were used.

\subsection{Host Plant Shifting and Acclimation}

Groups of 100 whitefly individuals (sex ratio 1:1) from the original colony reared on Chinese kale were transferred to insect-proof net cages $(22 \times 22 \times 22 \mathrm{~cm}$, Megaview). A total of five cages were used, each containing two plants of either Chinese kale, cotton, cucumber, poinsettia, or tomato. Two weeks later, all adult whiteflies were removed from the plants using a mouth aspirator, such that eggs and nymphs remained on the leaves. After the nymphs emerged to adults, 100 of the newly-emerged adult whiteflies were transferred to new net cages, each enclosed with two new host plants of the same species to breed the next generation. The whitefly colonies were reared on each host plant for 10 continuous generations.

\subsection{Performance of B. tabaci}

To determine the effects of host plant shifting and acclimation on the performance of B. tabaci, adult females were collected from the first and tenth generations on each host plant. Adult females were enclosed individually with a leaf of each host plant in a gauze bag $(6 \times 15 \mathrm{~cm}, 109$ mesh, Megaview) for oviposition. After $72 \mathrm{~h}$, the female was removed and the number of eggs counted using a stereomicroscope to determine its fecundity. The number of newly-emerged adults developing from the eggs was also recorded daily to calculate the developmental time and the survival rate of "egg and nymphal stages". The performance assay was conducted with 20 replicates per host plant for original, G1, and G10 colonies. The original colony represented the colony reared on Chinese kale. The data of original and G1 colonies were compared to examine the effect of host plant shifting, and the data of G1 and G10 colonies were compared to examine the effect of acclimation.

\subsection{Expression of Nutrient-Related Genes of P. aleyrodidarum}

To interpret the relationship between host plant shifting and acclimation and the expression of $P$. aleyrodidarum nutrient-related genes, the expression levels of essential amino acid biosynthesis genes $(\operatorname{trp} A, \operatorname{trp} B, l e u B, l e u C, i l v C$, and ilvD), which are encoded only in the genome of P. aleyrodidarum [26], were analyzed via a reverse transcription quantitative polymerase chain reaction (RT-qPCR) assay. Tryptophan, leucine and isoleucine biosynthesis cannot be completed by $B$. tabaci itself, and most essential genes in biosynthesis pathways are only present in P. aleyrodidarum. Therefore, we chose to examine these six genes from three amino acid biosynthesis pathways. For both the first and tenth generations of whiteflies, 25 males and 25 females were collected from each host plant. Each set of 5 males or 5 females was pooled to make single samples. Males and females were analyzed separately because females need more nutrients than males for reproduction [32]. The samples were then homogenized with $10 \mu \mathrm{L}$ of RLT buffer in a 1.5-mL eppendorf tube using a micropestle. Total RNA was extracted using a RNeasy Mini Kit (Qiagen, Valencia, CA, USA) following the manufacturer's instructions. Extracted RNA was then treated with a TURBO DNA-free Kit (Invitrogen, Carlsbad, CA, USA) to eliminate residual DNA. cDNA was synthesized from $500 \mathrm{ng}$ of RNA using a PrimeScript RT Reagent Kit (Takara Bio Inc., Kusatsu, Shiga, Japan) according to the manufacturer's instructions. SYBR green real-time PCR was then performed in a $20-\mu \mathrm{L}$ reaction volume, containing $10 \mu \mathrm{L}$ of $2 \times$ SensiFAST SYBR Hi-ROX Mix (Bioline, London, UK), $7 \mu \mathrm{L}$ of $\mathrm{ddH}_{2} \mathrm{O}, 0.5 \mu \mathrm{L}$ of each primer $(10 \mu \mathrm{M})$, and $2 \mu \mathrm{L}$ of the cDNA template. The primer sets used were gene-specific (Table 1) and designed in the present 
study by Primer Express Software (Applied Biosystems, Foster City, CA, USA) using the default criteria. The cycling conditions were as follows: one cycle of denaturation $\left(95^{\circ} \mathrm{C}, 5 \mathrm{~min}\right)$, followed by 40 cycles of denaturation $\left(95^{\circ} \mathrm{C}, 5 \mathrm{~s}\right)$, annealing $\left(60^{\circ} \mathrm{C}, 10 \mathrm{~s}\right)$, and extension $\left(72{ }^{\circ} \mathrm{C}, 20 \mathrm{~s}\right)$. The PCR efficiency of $\operatorname{trp} A, \operatorname{trp} B, \operatorname{leu} B, \operatorname{leu} C, i l v C$, ilvD, and gyr $A$ specific primer sets were $98.9 \%, 104.0 \%, 104.0 \% .100 .4 \%$, $98.5 \%, 102.7 \%$, and $105.6 \%$, respectively. Melting curves were generated at the end of the reaction to confirm the specificity of the amplification.

Table 1. Primers used to determine the expression levels of essential amino acid biosynthesis genes of P. aleyrodidarum.

\begin{tabular}{|c|c|c|c|}
\hline Gene & ID $^{1}$ & Sequence $\left(5^{\prime}\right.$ to $\left.3^{\prime}\right)$ & Amplicon \\
\hline $\operatorname{trp} A$ & Por0185 & $\begin{array}{l}\text { trpA-F: ACCACCAGAACACGCTCAAGAA } \\
\text { trpA-R: CTTCCTCCCGTAACTCCATTTATTG }\end{array}$ & $165 \mathrm{bp}$ \\
\hline $\operatorname{trp} B$ & Por0186 & $\begin{array}{l}\text { trpB-F: CGGGTCTAACGCAATGGGAT } \\
\text { trpB-R: ACTCCAGGCACACCTCCATTTAA }\end{array}$ & $135 \mathrm{bp}$ \\
\hline $\operatorname{leu} B$ & Por0099 & $\begin{array}{l}\text { leuB-F: TGGTATAGGGCCCGAAGTGATC } \\
\text { leuB-R: AGCGAGATGCTTTTGCTGCTT }\end{array}$ & $170 \mathrm{bp}$ \\
\hline leuC & Por0263 & $\begin{array}{l}\text { leuC-F: CAGATGGAGGCACAGGATATGC } \\
\text { leuC-R: CCAACTTTTGCTCCTGCTTCAA }\end{array}$ & $115 \mathrm{bp}$ \\
\hline$i l v C$ & Por0140 & $\begin{array}{l}\text { ilvC-F: TGTGGTGGCGTATCAGCATTAA } \\
\text { ilvC-R: TCACCCAAACCCCCTTCATATA }\end{array}$ & $140 \mathrm{bp}$ \\
\hline$i l v D$ & Por0090 & $\begin{array}{l}\text { ilvD-F: AGGCAATGGGACGTTGTTATCA } \\
\text { ilvD-R: CCACCCATTGCTATATCCATTATCAT }\end{array}$ & $180 \mathrm{bp}$ \\
\hline gyrA & Por0266 & $\begin{array}{l}\text { gyrA-F: TATGGCAACGAATGTACCTCCTC } \\
\text { gyrA-R: ACAATCCCAGCAGTCCCATAAAT }\end{array}$ & $159 \mathrm{bp}$ \\
\hline
\end{tabular}

The relative expression levels of the essential amino acid biosynthesis genes $(\operatorname{trp} A, \operatorname{trp} B, \operatorname{leuB}, \operatorname{leu} C$, $i l v C$, and $i l v D$ ) of $P$. aleyrodidarum were calculated using the $2^{-\Delta C t}$ method. gyr $A$ of $P$. aleyrodidarum was used as a normalization gene [33]. Each experiment was conducted using pooled samples of whiteflies from each host plant in the first and tenth generations with five biological replicates.

\subsection{Statistical Analyses}

The performance data of B. tabaci were analyzed by Kruskal-Wallis test with post-hoc Dunn's test. The gene expression data were first performed with normality transformation (logarithm transformation) and were then analyzed by one-way analysis of variance (ANOVA). When significant differences were observed, the Tukey test was employed as a post-hoc test after ANOVA. All data analyses were performed using SAS 9.4 (SAS Institute Inc., Cary, NC, USA).

\section{Results}

\subsection{Effects of Host Plant Shifting and Acclimation on the Performance of B. tabaci}

After the whiteflies had been reared on new host plants for 10 generations, they were considered acclimated to the new host plant. Thus, their performance at the first and tenth generations was evaluated and compared with that of the original colony. The survival rates of "egg and nymphal stages" of the first-generation whiteflies reared on each new host plant were not significantly different to those of the whiteflies from the original colony (Figure 1, Kruskal-Wallis test, Chinese kale: $p=0.52$; cucumber: $p=0.10$; cotton: $p=0.80$; poinsettia: $p=0.10$; tomato: $p=0.76$ ). The survival rates were also not significantly different after the whiteflies had become acclimated to each new host plant for 10 generations (Figure 1, Kruskal-Wallis test, Chinese kale: $p=0.52$; cucumber: $p=0.10$; cotton: $p=0.80$; poinsettia: $p=0.10$; tomato: $p=0.76$ ). 


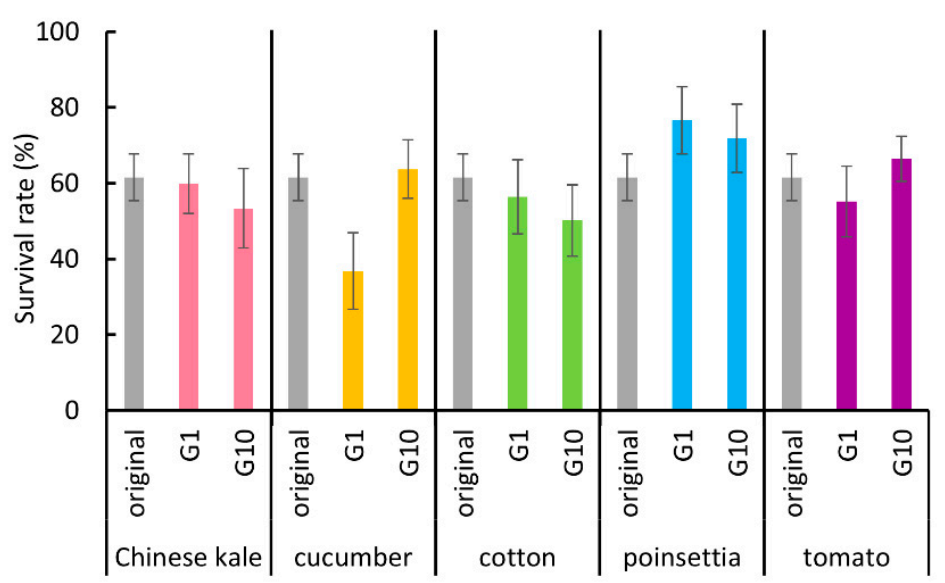

Figure 1. The survival rate of "egg and nymphal stages" of B. tabaci reared on each host plant in the first and tenth generations, and the original colony. Vertical bars indicate standard errors. There were no significant differences (Kruskal-Wallis test, $p>0.05$ ).

Regarding developmental time of "egg and nymphal stages", the transfer from Chinese kale to cucumber plants resulted in a significant decrease for the first generation, which slightly lengthened by the tenth generation (Figure 2, Dunn's test, $p<0.05$ ). For the group transferred from Chinese kale to cotton plants, developmental time for the first generation was not significantly different to that of the original colony (Dunn's test, $p>0.05$ ) but was significantly decreased by the tenth generation (Figure 2, Dunn's test, $p<0.05)$. For the groups transferred from Chinese kale to poinsettia and tomato plants, respectively, developmental time was significantly longer in comparison to the original colony for both generations (Figure 2, Dunn's test, $p<0.05$ ).

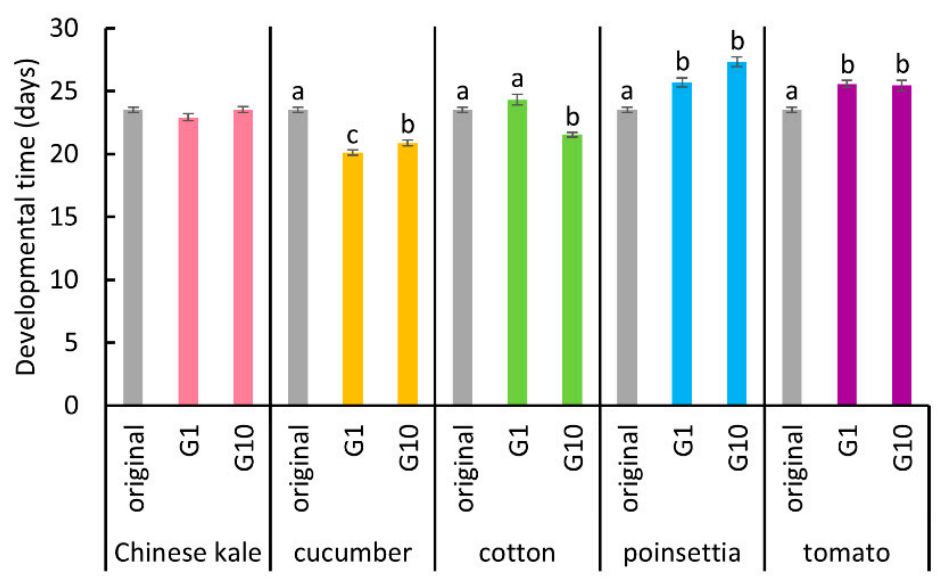

Figure 2. The developmental time of "egg and nymphal stages" of B. tabaci reared on each host plant in the first and tenth generations, and the original colony. Vertical bars indicate standard errors. Different letters indicate significant differences (Dunn's test, $p<0.05$ ).

The fecundity of the whiteflies was significantly reduced after they had been transferred from Chinese kale to cotton plants (Dunn's test, $p<0.05$ ) and then reverted to its original level after they had fed on cotton plants for 10 generations (Figure 3, Dunn's test, $p<0.05$ ). However, for transfers from Chinese kale to the other three host plants, no significant effects were observed (Figure 3, Kruskal-Wallis test, Chinese kale: $p=0.34$; cucumber: $p=0.70$; poinsettia: $p=0.08$; tomato: $p=0.37$ ). 


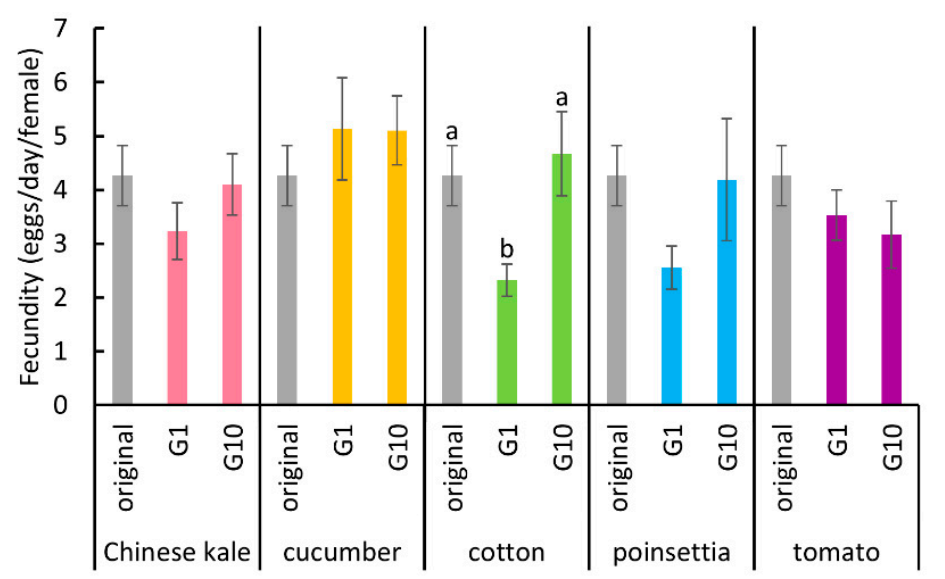

Figure 3. The fecundity of B. tabaci reared on each host plant in the first and tenth generations, and the original colony. Vertical bars indicate standard errors. Different letters indicate significant differences (Dunn's test, $p<0.05)$.

Taken together, it was found that host plant shifting and acclimation affect the performance of B. tabaci, especially on cotton plants.

\subsection{Relationship between Host Plant Shifting and Acclimation and the Expression of Nutrient-Related Genes of} P. aleyrodidarum

Since B. tabaci depends on P. aleyrodidarum to supplement several essential amino acids [27], we hypothesized that host plant acclimation is associated with this nutritional mutualistic endosymbiont. Therefore, we examined the expression levels of some tryptophan, leucine, and isoleucine biosynthesis genes $(\operatorname{trp} A, \operatorname{trp} B, l e u B, l e u C, i l v C$, and $i l v D)$ of P. aleyrodidarum for the whiteflies reared on each new host plant in the first and the tenth generations. Figures $4-7$ show the expression levels after $B$. tabaci was transferred to cucumber, cotton, poinsettia, and tomato, respectively.

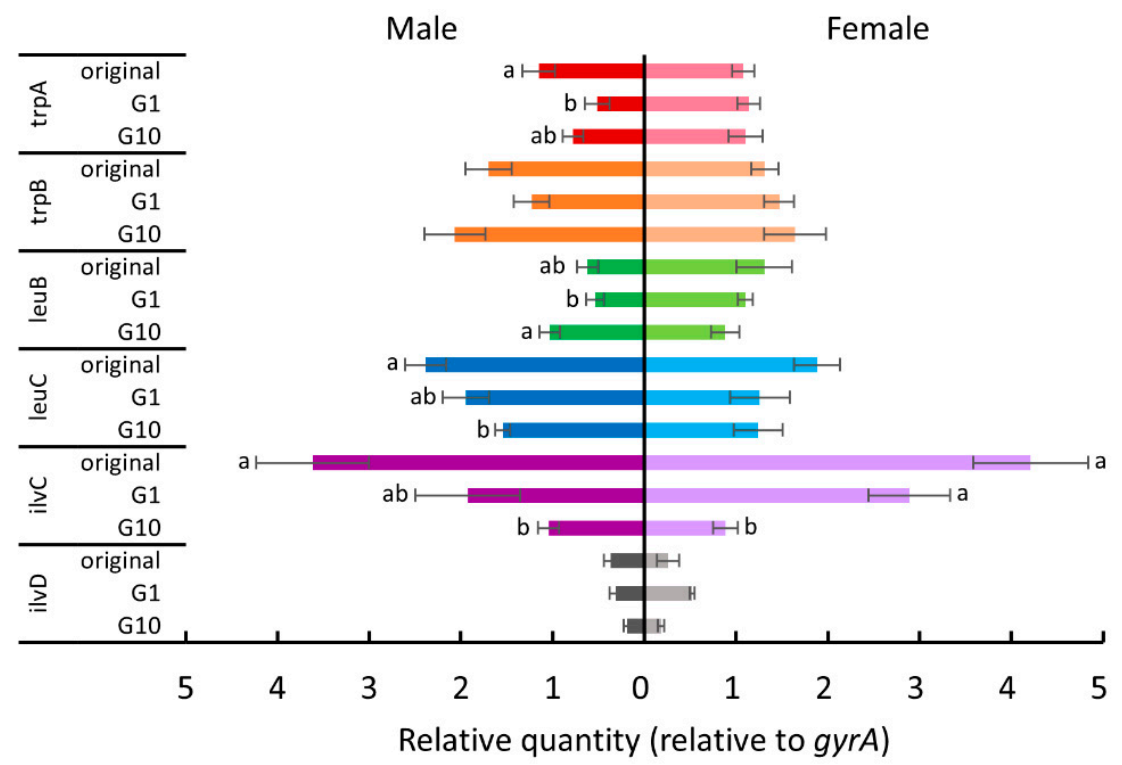

Figure 4. The expression levels of tryptophan, leucine, and isoleucine biosynthesis genes of $P$. aleyrodidarum in male and female $B$. tabaci reared on cucumber plants in the first and the tenth generations. Expression levels in the original colony are also shown. Horizontal bars indicate standard errors. Different letters indicate significant differences (Tukey test, $p<0.05$ ). 


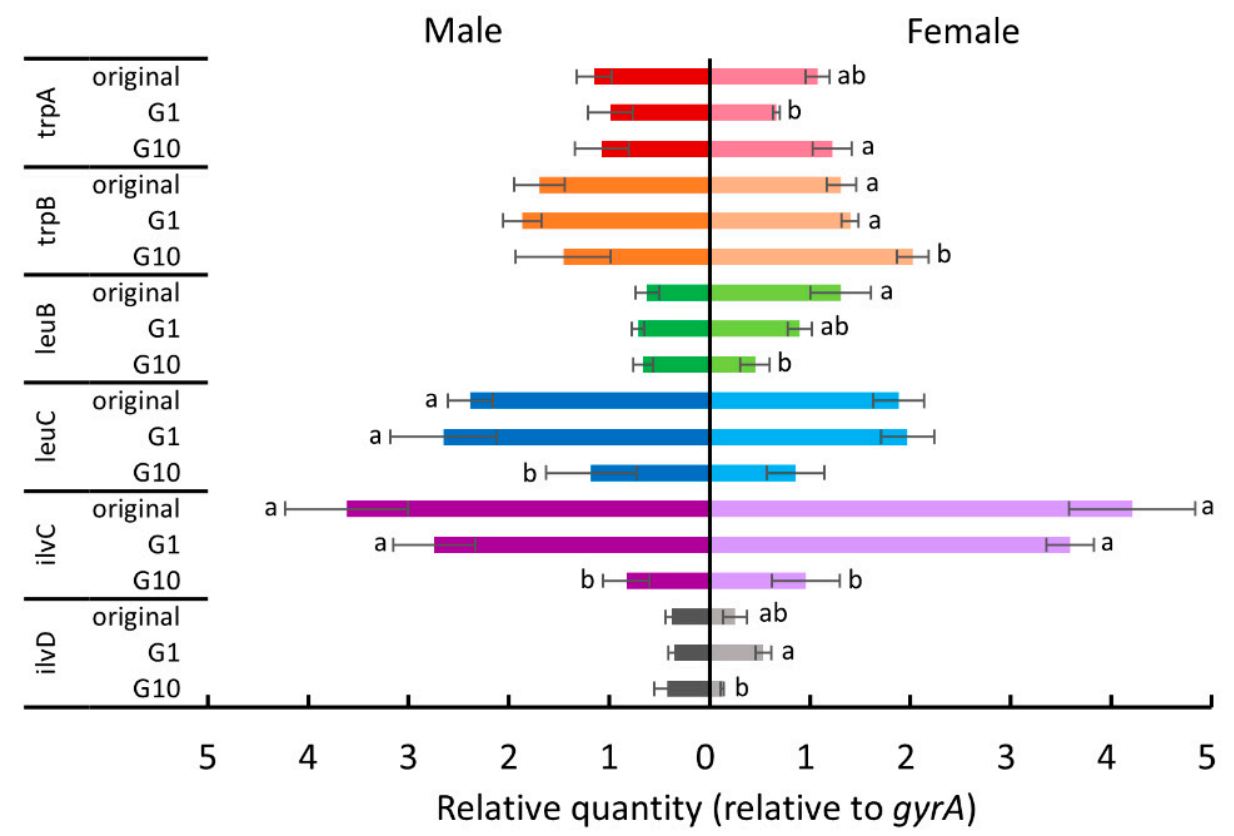

Figure 5. The expression levels of tryptophan, leucine, and isoleucine biosynthesis genes of $P$. aleyrodidarum in male and female $B$. tabaci reared on cotton plants in the first and the tenth generations. Expression levels in the original colony are also shown. Horizontal bars indicate standard errors. Different letters indicate significant differences (Tukey test, $p<0.05$ ).

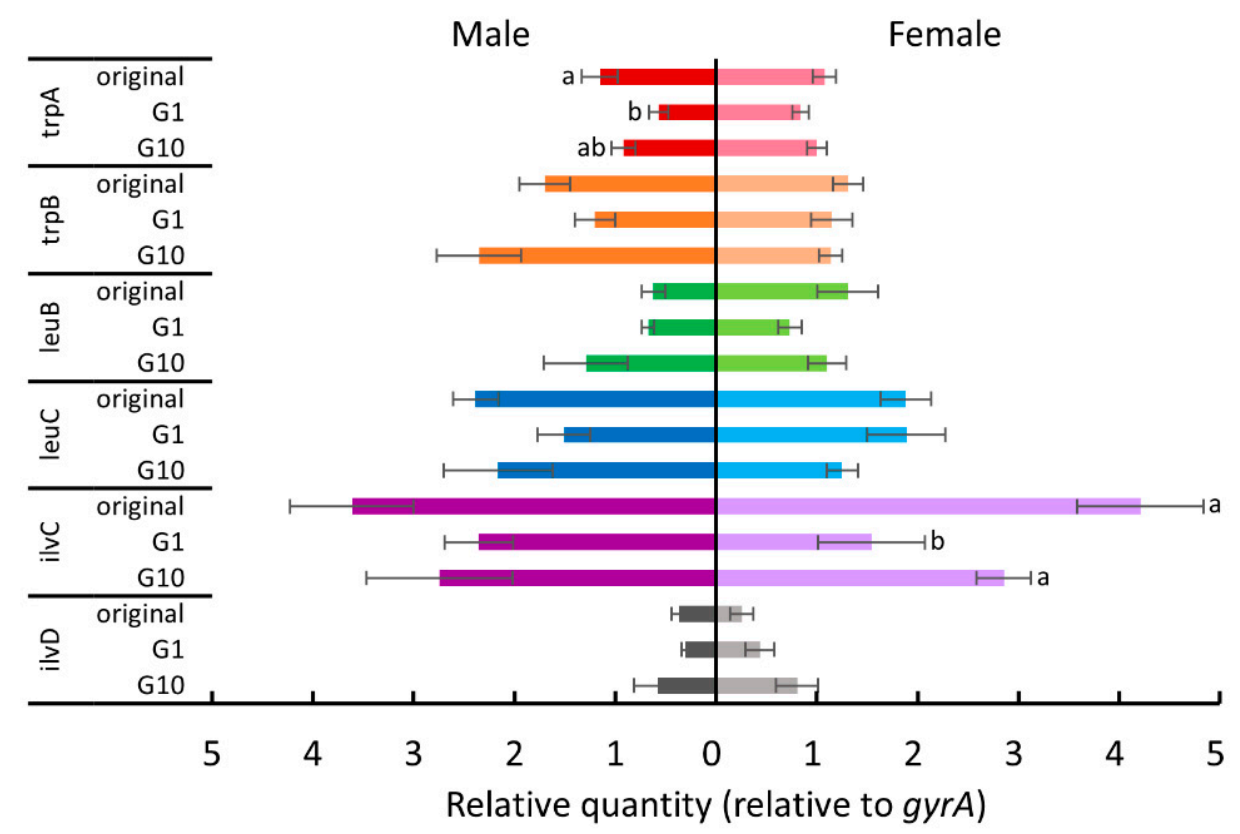

Figure 6. The expression levels of tryptophan, leucine, and isoleucine biosynthesis genes of P. aleyrodidarum in male and female B. tabaci reared on poinsettia in the first and the tenth generations. Expression levels in the original colony are also shown. Horizontal bars indicate standard errors. Different letters indicate significant differences (Tukey test, $p<0.05$ ). 


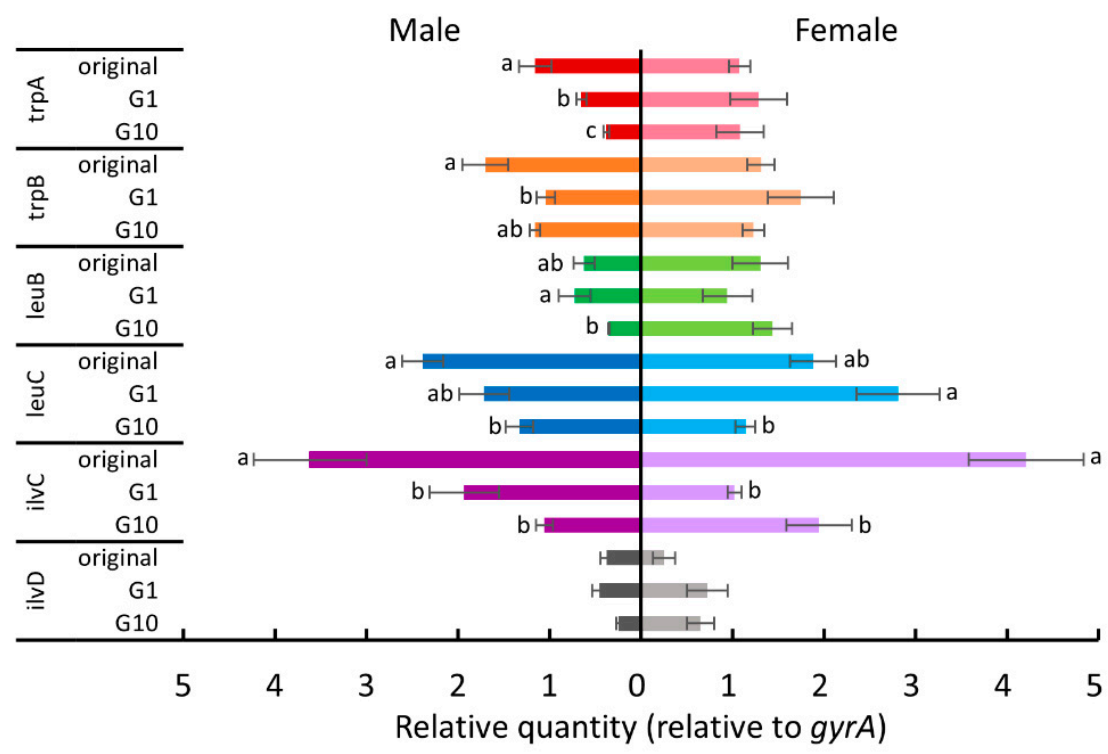

Figure 7. The expression levels of tryptophan, leucine, and isoleucine biosynthesis genes of $P$. aleyrodidarum in male and female $B$. tabaci reared on tomato plants in the first and the tenth generations. Expression levels in the original colony are also shown. Horizontal bars indicate standard errors. Different letters indicate significant differences (Tukey test, $p<0.05$ ).

For female whiteflies transferred to cucumber plants (Figure 4), ilvC expression was significantly downregulated in tenth-generation whiteflies (Tukey test, $p<0.05$ ). For males transferred to cucumber plants (Figure 4), $\operatorname{trp} A$ expression was significantly downregulated in the first generation (Tukey test, $p<0.05$ ), and leuB expression was significantly upregulated after 10 generations (Tukey test, $p<0.05$ ). The expression of both $l e u C$ and ilvC in tenth-generation males was significantly downregulated compared to that in the original colony (Tukey test, $p<0.05$ ).

For female whiteflies transferred to cotton plants (Figure 5), most genes were differentially expressed between the first and the tenth generations (Tukey test, $p<0.05$ ). The expression of both $\operatorname{trp} A$ and $\operatorname{trp} B$ was significantly upregulated (Tukey test, $p<0.05$ ), while that of $i l v C$ and $i l v D$ was significantly downregulated (Tukey test, $p<0.05$ ). For males transferred to cotton plants (Figure 5 ), there were no significant differences in the expression of all examined genes (one way-ANOVA, $\operatorname{trp} A$ : $p=0.83 ; \operatorname{trp} B: p=0.37 ;$ leuB: $p=0.72 ;$ ilv $D: p=0.99)$ except for leuC and ilv $C$, which were downregulated after 10 generations (Tukey test, $p<0.05$ ).

For female whiteflies transferred to poinsettia (Figure 6), ilvC expression was significantly downregulated in the first generation (Tukey test, $p<0.05$ ) and upregulated after 10 generations (Tukey test, $p<0.05$ ), whereas the expression of all other genes did not show significant differences between the first and tenth generations (one way-ANOVA, $\operatorname{trp} A: p=0.23 ; \operatorname{trp} B: p=0.64 ; \operatorname{leuB}: p=0.20$; leuC: $p=0.26$; ilvD: $p=0.10$ ). For males transferred to poinsettia (Figure 6), $\operatorname{tr} p A$ expression was significantly downregulated in the first generation (Tukey test, $p<0.05$ ). The other examined genes did not show differences in expression level after being transferred to this host plant (one way-ANOVA, $\operatorname{trp} B: p=0.054$; leuB: $p=0.71$; leuC: $p=0.28$; ilv $C: p=0.49$; ilvD: $p=0.56$ ).

For female whiteflies transferred to tomato plants (Figure 7), ilvC expression was significantly downregulated in the first generation (Tukey test, $p<0.05$ ), and leuC expression was significantly downregulated after 10 generations (Tukey test, $p<0.05$ ). For males transferred to tomato plants (Figure 7), the expression of $\operatorname{trp} A, \operatorname{trp} B$, and ilv $C$ was significantly downregulated after being transferred to tomato plants (Tukey test, $p<0.05$ ), and $\operatorname{trp} A$ expression was further downregulated after 10 generations (Tukey test, $p<0.05$ ). In addition, leuB expression was significantly downregulated after 10 generations (Tukey test, $p<0.05$ ), and leuC expression was significantly downregulated in the tenth generation compared to that of the original colony (Tukey test, $p<0.05$ ). 
In summary, the biosynthesis of the essential amino acids provided by $P$. aleyrodidarum was regulated during host plant shifting and acclimation, especially when $B$. tabaci acclimated to cotton plants (Figure 8).
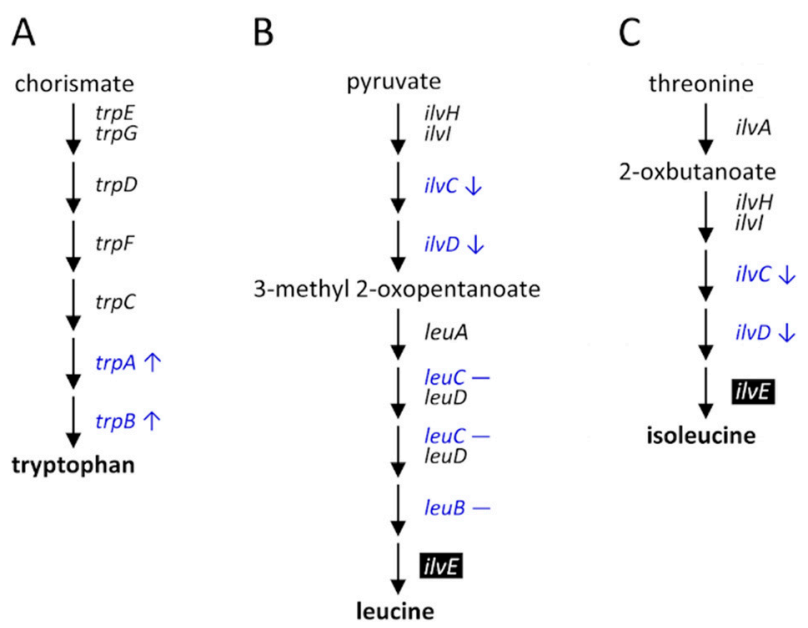

Figure 8. Differential expression of the genes in essential amino acid biosynthesis pathways of P. aleyrodidarum in female B. tabaci reared on cotton plants between the first and the tenth generations: (A) tryptophan, (B) leucine, and (C) isoleucine. Reverse type indicates genes that exist only in B. tabaci and blue font indicates those examined in the present study. Up and down arrows indicate that gene expression was up- and downregulated, respectively, in the tenth generation. Dash indicates no differential expression between the first and the tenth generations.

\section{Discussion}

In the present study, we investigated the effect of transferring B. tabaci from Chinese kale to four different host plants. Since the nutrient composition and defensive compounds of the phloem sap differ in each host plant, the performance of $B$. tabaci may be improved or impaired. This is reflected in our results, whereby the developmental time of $B$. tabaci was significantly altered by the transfer from Chinese kale to cucumber, poinsettia, and tomato plants, with an impact on the first generation. Furthermore, the fecundity of $B$. tabaci was significantly reduced after being transferred from Chinese kale to cotton plants. A similar effect has also been recorded in other plant sap-sucking insects such as Ac. pisum, which displays lower fitness after it has been transferred from Vicia faba to V. villosa, Medicago sativa, and M. truncatula [34]. Zhang et al. [35] also reported that when Aphis gossypii is transferred from cotton to cowpea, pumpkin, and zucchini, the amount of Buchnera (the primary endosymbiont of Ap. gossypii) becomes unstable, and the survival rates of Ap. gossypii significantly decrease. Host plant shifting is, therefore, a challenge for both the directly-affected insects and their indirectly-affected endosymbionts; there are new diet conditions and defensive compounds that may require acclimation.

In the present study, the expression levels of selected amino acid biosynthesis genes of $P$. aleyrodidarum were differentially regulated when $B$. tabaci was transferred or acclimated to some host plants. This may be the result of the endosymbionts responding to physiological conditions in the insect host or the host manipulating its endosymbionts to correspond with its physiological conditions [36]. For example, the lysosomal system of Ac. pisum is involved with the degradation of its primary endosymbiont, Buchnera, and cereal weevils (Sitophilus spp.) also can digest and recycle their primary endosymbiont, Sodalis pierantonius, by cell apoptosis and autophagy activation after their exoskeleton is formed [37,38]. To overcome defensive compounds or to compensate for the different nutrient compositions in new host plants, B. tabaci may actively manipulate the amount and activities of its endosymbionts during host plant acclimation. The performance of B. tabaci may consequently be influenced. 
Notably, the fecundity of $B$. tabaci was restored and the developmental time decreased after it had been reared on cotton plants for 10 generations. Also, the expression of $\operatorname{trp} A$ and $\operatorname{trp} B$ was upregulated, and that of $i l v C$ and $i l v D$ was downregulated after 10 generations. One possible explanation of the improved performance of $B$. tabaci is that it manipulates the expression of essential amino acid biosynthesis genes of P. aleyrodidarum, thus helping it to overcome the changing nutrient conditions in the phloem sap. This explanation is supported by a study revealing that none of the regulatory genes related to amino acid biosynthesis were found in P. aleyrodidarum, which suggests that it is B. tabaci, not $P$. aleyrodidarum, that can regulate the biosynthesis of amino acids [39]. Moreover, one generation may be insufficient for B. tabaci to respond to the different diet conditions between the phloem sap of cotton and Chinese kale, which could explain why the fecundity of first-generation whiteflies was lower than that of the original colony. Our findings suggest that the differential expression of essential amino acid biosynthesis genes of $P$. aleyrodidarum is positively associated with the performance of $B$. tabaci reared on cotton plants. Further research is warranted to investigate the mechanism of how P. aleyrodidarum improves the performance of $B$. tabaci on cotton plants.

The expression levels of few selected amino acid biosynthesis genes of $P$. aleyrodidarum were regulated after B. tabaci were transferred from Chinese kale to tomato and poinsettia for 10 generations. The differentially regulated genes varied depending on host plant and were different between males and females. Since the developmental time of B. tabaci increased after 10 generations, B. tabaci may not acclimate to poinsettia and tomato within 10 generations. The causes of differential expression between males and females are not clear. One possible reason is that females need more nutrients than males for reproduction [32]. Further research is warranted to investigate the mechanism of why the expression of the selected genes was different between males and females.

Although the expression levels of some selected amino acid biosynthesis genes of $P$. aleyrodidarum were significantly regulated after $B$. tabaci was transferred from Chinese kale to tomato, the performance of $B$. tabaci decreased. This suggests that nutritional regulation manipulated by $B$. tabaci may not be the only factor that affects whitefly performance. Other factors, such as mechanical defense and defensive compounds in plants, may also affect their performance and physiological condition. Rakha et al. [40] reported that a high density of type IV trichomes on tomato leaves reduces infestation by $B$. tabaci and increases their mortality, which suggests higher resistance toward whiteflies. In addition, we cannot rule out the possibility that the differences between the first and tenth generations could potentially be due to random fluctuations rather than actual acclimation.

Since endosymbionts have close relationships with their insect hosts in many aspects, the potential use of symbionts as tools to control insect pests and vector-borne diseases has received considerable attention in recent years [41]. Indeed, several strategies for controlling vector-borne plant diseases and insect pests of crops have been proposed to target insect endosymbionts [42]. Paratransgenesis, which modifies the symbiotic microorganisms by genetic transformation, is a conceivable approach. This has been shown, for example, by Arora et al. [43] in a study of Pantoea agglomerans, a symbiont of Homalodisca vitripennis that transmits Xylella fastidiosa causing Pierce's disease in grapevines. They genetically engineered $P$. agglomerans to express antimicrobial peptides, which successfully killed X. fastidiosa in its insect vector [43]. Therefore, a greater understanding of the interactions among B. tabaci, its endosymbionts, and the host plant may lead to novel strategies in the control of $B$. tabaci.

\section{Conclusions}

The present results demonstrate that host shifting from Chinese kale to cotton plants leads to a decrease in the performance of $B$. tabaci in the first generation, which is restored by the tenth generation. Furthermore, after B. tabaci has acclimated to the cotton plants, the expression levels of essential amino acid biosynthesis genes of its primary endosymbiont, P. aleyrodidarum, are differentially regulated. The present study suggests that $P$. aleyrodidarum may help B. tabaci improve its performance and acclimate to new host plants and that $P$. aleyrodidarum has a close nutritional relationship with its host during host plant acclimation. 
Author Contributions: Conceptualization, F.-Y.H. and C.-W.T.; Data curation, F.-Y.H. and C.-W.T.; Formal analysis, F.-Y.H. and C.-W.T.; Methodology, F.-Y.H. and C.-W.T.; Supervision, C.-W.T.; Writing-original draft, F.-Y.H.; Writing-review \& editing, C.-W.T. All authors have read and agreed to the published version of the manuscript.

Funding: This research was supported by the Ministry of Science and Technology of Taiwan, grant number MOST 106-2313-B-002-016.

Acknowledgments: The authors would like to thank Alexander C. Barton for editing this manuscript.

Conflicts of Interest: The authors declare no conflict of interest.

\section{References}

1. Baumann, P. Biology of bacteriocyte-associated endosymbionts of plant sap-sucking insects. Annu. Rev. Microbiol. 2005, 59, 155-189. [CrossRef] [PubMed]

2. Douglas, A.E. The microbial dimension in insect nutritional ecology. Funct. Ecol. 2009, 23, 38-47. [CrossRef]

3. Bourtzis, K.; Miller, T.A. Insect Symbiosis, Volume 2; CRC Press: Boca Raton, FL, USA, 2006; p. 304.

4. Oliver, K.M.; Russell, J.A.; Moran, N.A.; Hunter, M.S. Facultative bacterial symbionts in aphids confer resistance to parasitic wasps. Proc. Natl. Acad. Sci. USA 2003, 100, 1803-1807. [CrossRef] [PubMed]

5. Xie, J.; Vilchez, I.; Mateos, M. Spiroplasma bacteria enhance survival of Drosophila hydei attacked by the parasitic wasp Leptopilina heterotoma. PLoS ONE 2010, 5, e12149. [CrossRef] [PubMed]

6. Scarborough, C.L.; Ferrari, J.; Godfray, H.C.J. Aphid protected from pathogen by endosymbiont. Science 2005, 310, 1781. [CrossRef]

7. Łukasik, P.; van Asch, M.; Guo, H.; Ferrari, J.; Godfray, H.C.J. Unrelated facultative endosymbionts protect aphids against a fungal pathogen. Ecol. Lett. 2013, 16, 214-218. [CrossRef]

8. Tsuchida, T.; Koga, R.; Horikawa, M.; Tsunoda, T.; Maoka, T.; Matsumoto, S.; Simon, J.C.; Fukatsu, T. Symbiotic bacterium modifies aphid body color. Science 2010, 330, 1102-1104. [CrossRef] [PubMed]

9. Brumin, M.; Kontsedalov, S.; Ghanim, M. Rickettsia influences thermotolerance in the whitefly Bemisia tabaci B biotype. Insect Sci. 2011, 18, 57-66. [CrossRef]

10. Wernegreen, J.J. Mutualism meltdown in insects: Bacteria constrain thermal adaptation. Curr. Opin. Microbiol. 2012, 15, 255-262. [CrossRef]

11. Kontsedalov, S.; Zchori-Fein, E.; Chiel, E.; Gottlieb, Y.; Inbar, M.; Ghanim, M. The presence of Rickettsia is associated with increased susceptibility of Bemisia tabaci (Homoptera: Aleyrodidae) to insecticides. Pest Manag. Sci. 2008, 64, 789-792. [CrossRef]

12. Kikuchi, Y.; Hayatsu, M.; Hosokawa, T.; Nagayama, A.; Tago, K.; Fukatsu, T. Symbiont-mediated insecticide resistance. Proc. Natl. Acad. Sci. USA 2012, 109, 8618-8622. [CrossRef] [PubMed]

13. Gottlieb, Y.; Fein, E.Z.; Mozes-Daube, N.; Kontsedalov, S.; Skaljac, M.; Brumin, M.; Sobol, I.; Czosnek, H.; Vavre, F.; Fleury, F.; et al. The transmission efficiency of Tomato yellow leaf curl virus by the whitefly Bemisia tabaci is correlated with the presence of a specific symbiotic bacterium species. J. Virol. 2010, 84, 9310-9317. [CrossRef] [PubMed]

14. Rana, V.S.; Singh, S.T.; Priya, N.G.; Kumar, J.; Rajagopal, R. Arsenophonus GroEL interacts with CLCuV and is localized in midgut and salivary gland of whitefly B. tabaci. PLOS ONE 2012, 7, e42168. [CrossRef] [PubMed]

15. Su, Q.; Pan, H.; Liu, B.; Chu, D.; Xie, W.; Wu, Q.; Wang, S.; Xu, B.; Zhang, Y. Insect symbiont facilitates vector acquisition, retention, and transmission of plant virus. Sci. Rep. 2013, 3, 1367. [CrossRef] [PubMed]

16. White, J.A.; Kelly, S.E.; Perlman, S.J.; Hunter, M.S. Cytoplasmic incompatibility in the parasitic wasp Encarsia inaron: Disentangling the roles of Cardinium and Wolbachia symbionts. Heredity 2009, 102, 483-489. [CrossRef] [PubMed]

17. Bourtzis, K.; Miller, T.A. Insect Symbiosis; CRC Press: Boca Raton, FL, USA, 2003; p. 368.

18. De Barro, P.J.; Liu, S.S.; Boykin, L.M.; Dinsdale, A.B. Bemisia tabaci: A statement of species status. Annu. Rev. Entomol. 2011, 56, 1-19. [CrossRef]

19. Boykin, L.M.; De Barro, P.J. A practical guide to identifying members of the Bemisia tabaci species complex: And other morphologically identical species. Front. Ecol. Evol. 2014, 2, 45. [CrossRef]

20. Alemandri, V.; Vaghi Medina, C.G.; Dumón, A.D.; Argüello Caro, E.B.; Mattio, M.F.; García Medina, S.; López Lambertini, P.M.; Truol, G. Three members of the Bemisia tabaci (Hemiptera: Aleyrodidae) cryptic species complex occur sympatrically in Argentine horticultural crops. J. Econ. Entomol. 2015, 108, 405-413. [CrossRef] 
21. Wang, H.L.; Lei, T.; Xia, W.Q.; Cameron, S.L.; Liu, Y.Q.; Zhang, Z.; Gowda, M.M.N.; De Barro, P.; Navas-Castillo, J.; Omongo, C.A.; et al. Insight into the microbial world of Bemisia tabaci cryptic species complex and its relationships with its host. Sci. Rep. 2019, 9, 6568. [CrossRef]

22. Malka, O.; Santos-Garcia, D.; Feldmesser, E.; Sharon, E.; Krause-Sakate, R.; Delatte, H.; van Brunschot, S.; Patel, M.; Visendi, P.; Mugerwa, H.; et al. Species-complex diversification and host-plant associations in Bemisia tabaci: A plant-defence, detoxification perspective revealed by RNA-Seq analyses. Mol. Ecol. 2018, 27, 4241-4256. [CrossRef]

23. Santos-Garcia, D.; Farnier, P.A.; Beitia, F.; Zchori-Fein, E.; Vavre, F.; Mouton, L.; Moya, A.; Latorre, A.; Silva, F.J. Complete genome sequence of "Candidatus Portiera aleyrodidarum" BT-QVLC, an obligate symbiont that supplies amino acids and carotenoids to Bemisia tabaci. J. Bacteriol. 2012, 194, 6654-6655. [CrossRef] [PubMed]

24. Sloan, D.B.; Moran, N.A. Endosymbiotic bacteria as a source of carotenoids in whiteflies. Biol. Lett. 2012, 8, 986-989. [CrossRef] [PubMed]

25. Luan, J.B.; Chen, W.; Hasegawa, D.K.; Simmons, A.M.; Wintermantel, W.M.; Ling, K.S.; Fei, Z.; Liu, S.S.; Douglas, A.E. Metabolic coevolution in the bacterial symbiosis of whiteflies and related plant sap-feeding insects. Genome Biol. Evol. 2015, 7, 2635-2647. [CrossRef]

26. Chen, W.; Hasegawa, D.K.; Kaur, N.; Kliot, A.; Pinheiro, P.V.; Luan, J.; Stensmyr, M.C.; Zheng, Y.; Liu, W.; Sun, H.; et al. The draft genome of whitefly Bemisia tabaci MEAM1, a global crop pest, provides novel insights into virus transmission, host adaptation, and insecticide resistance. BMC Biol. 2016, 14, 110. [CrossRef]

27. Ankrah, N.Y.D.; Luan, J.; Douglas, A.E. Cooperative metabolism in a three-partner insect-bacterial symbiosis revealed by metabolic modeling. J. Bacteriol. 2017, 199, e00872-16. [CrossRef] [PubMed]

28. Hansen, A.K.; Moran, N.A. Aphid genome expression reveals host-symbiont cooperation in the production of amino acids. Proc. Natl. Acad. Sci. USA 2011, 108, 2849-2854. [CrossRef]

29. Santos-Garcia, D.; Mestre-Rincon, N.; Zchori-Fein, E.; Morin, S. Inside out: Microbiota dynamics during host-plant adaptation of whiteflies. ISME J. 2020, 14, 847-856. [CrossRef] [PubMed]

30. Weng, S.H.; Tsai, W.S.; Kenyon, L.; Tsai, C.W. Different transmission efficiencies may drive displacement of tomato begomoviruses in the fields in Taiwan. Ann. Appl. Biol. 2015, 166, 321-330. [CrossRef]

31. Ansari, P.G.; Singh, R.K.; Kaushik, S.; Krishna, A.; Wada, T.; Noda, H. Detection of symbionts and virus in the whitefly Bemisia tabaci (Hemiptera: Aleyrodidae), vector of the Mungbean yellow mosaic India virus in Central India. Appl. Entomol. Zool. 2017, 52, 567-579. [CrossRef]

32. Chapman, R.F. The Insects: Structure and Function, 4th ed.; Cambridge University Press: Cambridge, UK, 1998; p. 770.

33. Rocha, D.J.P.; Santos, C.S.; Pacheco, L.G.C. Bacterial reference genes for gene expression studies by RT-qPCR: Survey and analysis. Antonie Van Leeuwenhoek 2015, 108, 685-693. [CrossRef] [PubMed]

34. Lu, H.; Yang, P.; Xu, Y.; Luo, L.; Zhu, J.; Cui, N.; Kang, L.; Cui, F. Performances of survival, feeding behavior, and gene expression in aphids reveal their different fitness to host alteration. Sci. Rep. 2016, 6, 19344. [CrossRef] [PubMed]

35. Zhang, Y.C.; Cao, W.J.; Zhong, L.R.; Godfray, H.C.J.; Liu, X.D. Host plant determines the population size of an obligate symbiont (Buchnera aphidicola) in aphids. Appl. Environ. Microbiol. 2016, 82, 2336-2346. [CrossRef] [PubMed]

36. Hansen, A.K.; Moran, N.A. The impact of microbial symbionts on host plant utilization by herbivorous insects. Mol. Ecol. 2014, 23, 1473-1496. [CrossRef] [PubMed]

37. Nishikori, K.; Morioka, K.; Kubo, T.; Morioka, M. Age- and morph-dependent activation of the lysosomal system and Buchnera degradation in aphid endosymbiosis. J. Insect. Physiol. 2009, 55, 351-357. [CrossRef] [PubMed]

38. Vigneron, A.; Masson, F.; Vallier, A.; Balmand, S.; Rey, M.; Vincent-Monégat, C.; Aksoy, E.; Aubailly-Giraud, E.; Zaidman-Rémy, A.; Heddi, A. Insects recycle endosymbionts when the benefit is over. Curr. Biol. 2014, 24, 2267-2273. [CrossRef]

39. Zhu, D.; Zou, C.; Ban, F.; Wang, H.; Wang, X.; Liu, Y. Conservation of transcriptional elements in the obligate symbiont of the whitefly Bemisia tabaci. PeerJ 2019, 7, e7477. [CrossRef]

40. Rakha, M.; Hanson, P.; Ramasamy, S. Identification of resistance to Bemisia tabaci Genn. in closely related wild relatives of cultivated tomato based on trichome type analysis and choice and no-choice assays. Genet. Resour. Crop Evol. 2017, 64, 247-260. [CrossRef] 
41. Chuche, J.; Auricau-Bouvery, N.; Danet, J.L.; Thiéry, D. Use the insiders: Could insect facultative symbionts control vector-borne plant diseases? J. Pest Sci. 2017, 90, 51-68. [CrossRef]

42. Douglas, A.E. Symbiotic microorganisms: Untapped resources for insect pest control. Trends Biotechnol. 2007, 25, 338-342. [CrossRef] [PubMed]

43. Arora, A.K.; Pesko, K.N.; Quintero-Hernández, V.; Possani, L.D.; Miller, T.A.; Durvasula, R.V. A paratransgenic strategy to block transmission of Xylella fastidiosa from the glassy-winged sharpshooter Homalodisca vitripennis. BMC Biotechnol. 2018, 18, 50. [CrossRef]

(C) 2020 by the authors. Licensee MDPI, Basel, Switzerland. This article is an open access article distributed under the terms and conditions of the Creative Commons Attribution (CC BY) license (http://creativecommons.org/licenses/by/4.0/). 